\title{
PENGARUH MEDIA TANAM DAN BERAT BENIH TERHADAP PERTUMBUHAN VEGETATIF AWAL BENIH KOPI ARABIKA \\ (Coffea arabica L. )
}

\section{THE EFFECT OF PLANT MEDIA AND WEIGHT SEED ON EARLY VEGETATIVE GROWTH OF ARABICAN COFFEE SEED (Coffea arabica L. )}

\author{
Toto Suharjanto ${ }^{1)}$, Tri Wardhani ${ }^{1)}$ dan Risfandi ${ }^{1)}$ \\ ${ }^{1)}$ Jurusan Agroteknologi, Fakultas Pertanian, Universitas Widyagama Malang \\ Email: totosuharjanto@gmail.com
}

\begin{abstract}
ABSTRAK
Tanaman kopi merupakan komoditas perkebunan yang banyak dibudidayakan di Indonesia. Penelitian ini bertujuan mengetahui pengaruh media tanam dan berat benih terhadap pertumbuhan vegetatif awal kopi arabika. Penelitian merupakan percobaan faktorial yang disusun dengan rancangan acak lengkap (RAL). Faktor pertama adalah media tanam M0 ( tanah), M1 (tanah + sekam, M2 (tanah + pupuk kandang), dan M3 (tanah + sekam + pupuk kandang). Faktor kedua adalah berat benih per 100 Butir dengan 3 taraf yaitu B1 (berat 21 gram), B2 (24 gram), dan B3 ( 26 gram). Hasil penelitian menunjukkan bahwa kombinasi perlakuan media tanam dan berat benih kopi arabika tidak berpengaruh terhadap persentase daya perkecambahan kopi arabika dan jumlah daun bibit kopi. Sementara itu masing-masing perlakuan media tanam dan perlakuan berat benih berpengaruh nyata terhadap persentase perkecambahan benih kopi dan tinggi bibit kopi. Perlakuan media tanam M3 mengakibatkan daya kecambah yang paling tinggi, begitu pula dengan perlakuan berat benih B3. Hal yang sama berlaku juga untuk variabel pengamatan tinggi bibit kopi arabika.
\end{abstract}

Kata kunci: berat benih, kopi arabika, media tanam

\begin{abstract}
Coffee is a plantation commodity that is widely cultivated in Indonesia. This study aims to determine the effect of planting media and seed weight on the initial vegetative growth of arabica coffee. The research is a factorial experiment that was arranged in a completely randomized design (CRD). The first factor is planting media MO (soil), M1 (soil + husk), M2 (soil + manure), and M3 (soil + husk + manure). The second factor is the weight of the seed per 100 grains with 3 levels, namely B1 (21 grams), B2 (24 grams), and B3 (26 grams). The results showed that the combination of the treatment of planting media and arabica coffee seed weight did not affect the percentage of germination of arabica coffee and the number of leaves of coffee seedlings. Planting media and treatment of seed weight significantly affected the germination rate of coffee seeds and the height of coffee seedlings.The treatment of M3 planting media resulted in the highest germination, as well as the treatment of B3 seed weight. The same
\end{abstract}


treatment gave same effect to the observation variables of arabica coffee seedling height.

Keywords: seed weight, arabica coffee, planting media

\section{PENDAHULUAN}

Tanaman kopi merupakan komoditas perkebunan yang banyak dibudidayakan di Indonesia. Selain sebagai sumber mata pencaharian yang erat hubungannya dengan kesejahteraan, hasil panen dapat memberi sumbangan cukup besar sebagai sumber devisa dalam menopang pembangunan nasional. Petani Indonesia memiliki lahan tanaman kopi dengan rata-rata luas yang berkisar antara 0,5 sampai 1 hektar. Pada tahun 2004 luas areal perkebunan kopi mencapai 1,3 juta hektar dengan produksi sebesar 675 ribu ton, dengan produktifitas 2 ton/ha/thn (Anonim, 2011).

Pengadaan bibit kopi arabika dapat dilakukan secara generatif dan vegetatif di persemaian. Benih yang disemai dapat tumbuh dengan baik jika pada pemeliharaan persemaian dilakukan dengan perbaikan teknik budidaya tanaman kopi antara lain dengan memberi zat perangsang tumbuh. Zat perangsang tumbuh mengandung hormon-hormon pertumbuhan atau zat aktif yang bisa memacu tanaman tumbuh pesat. Untuk mengoptimalkan pertumbuhan benih kopi maka hal yang perlu diperhatikan adalah pemeliharaan benih kopi dengan pemberian hormon pertumbuhan dengan konsentrasi yang tepat.

Salah satu yang harus diperhatikan dalam budidaya kopi adalah saat menyiapkan bibit kopi. Pembibitan merupakan langkah awal dari seluruh rangkaian kegiatan budidaya kopi yang sangat berpengaruh terhadap produktivitas tanaman dan umur produktif.

Media tanam merupakan salah satu syarat supaya tanaman kopi dapat tumbuh dengan baik. Kondisi media tanam yang meliputi sifat fisik, kimia dan biologis sangat mempengaruhi hasil bercocok tanam yang baik kualitas. Campuran beberapa bahan untuk media tanam harus menghasilkan struktur yang sesuai karena setiap jenis media 
mempunyai pengaruh yang berbeda bagi tanaman. Menurut Suteja dan Kartasapoetra (1992) bahwa media tanam dapat diperbaiki dengan pemberian bahan organik seperti kompos, pupuk kandang atau bahan organik lain.

Tanah yang berstruktur remah sangat baik untuk pertumbuhan dan perkembangan tanaman, karena di dalamnya mengandung bahan organik yang merupakan sumber ketersediaan hara bagi tanaman (Dwidjoseputro, 1998). Kadar humus dapat ditingkatkan dengan menambahkan bahan organik yang berasal dari pupuk kandang untuk mendorong populasi mikrobia di dalam tanah menjadi jauh lebih banyak dibandingkan jika yang diberikan pupuk kimia buatan (Lingga, 1998).

\section{METODE PENELITIAN}

Penelitian dilaksanakan pada bulan Februari-Apil 2018 di Dusun Sumber, Desa Wonosalam, Kecamatan Wonosalam, Kabupaten Jombang dengan ketinggian 800 meter di atas permukaan laut, suhu rata-rata $19^{\circ-} 24^{\circ} \mathrm{C}$, curah hujan 2000 -
$3000 \mathrm{~mm} /$ tahun (BMKG kabupaten Jombang, 2012).

Hasil penelitian Sari, et al., 2019 menunjukkan bahwa komposisi media tanam berpengaruh sangat nyata terhadap variabel pertumbuhan bibit kopi seperti diamater batang pada 60 dan 90 HST, serta pada bobot brangkasan basah, bobor brangkasan kering kering dan volume akar pada 30 HST. Komposisi media tanam terbaik adalah perbandingan tanah: pupuk kandang (2:1).

Penelitian ini menggunakan Rancangan Acak Lengkap (RAL) faktorial. Dengan ulangan 3 kali, masing-masing unit terdapat 2 sampel. Faktor I adalah Media Tanam dengan 4 taraf yaitu M0 (tanah), M1 (tanah dicampur dengan sekam, M2 (tanah dicampur pupuk kandang), dan M3 (tanah dicampur sekam dan pupuk kandang). Faktor II adalah berat benih per 100 Butir dengan 3 taraf yaitu B1 (berat benih kopi arabika 21 gram), B2 (berat benih kopi arabika 24 gram), dan B3 (berat benih kopi arabika 26 gram).

Penelitian dilaksanakan dengan beberapa tahapan yaitu persiapan 
media tanam, pemilihan (Sortasi) benih kopi Arabika, perendaman benih kopi Arabika, penyemaian benih kopi Arabika, pemindahan bibit kopi Arabika ke Polybag dan penyiraman.

Adapun Variabel pengamatan meliputi persentase daya perkecambahan, tinggi tanaman.dan jumlah daun. Data hasil pengamatan dianalisa dengan menggunakan analisa ragam untuk mengetahui ada atau tidaknya pengaruh perlakuan. Apabila ada perbedaan diantara perlakuan dilakukan Uji lanjut Beda Nyata Jujur (BNJ) dengan $\alpha 5 \%$.

\section{HASIL DAN PEMBAHASAN}

Hasil analisis ragam menunjukkan bahwa tidak terdapat pengaruh interaksi yang nyata pada perlakuan media tanam (M) dan berat benih (B) terhadap persentase daya perkecambahan kopi arabika. Perlakuan media tanam (M) dan berat benih kopi (B) secara tunggal berpengaruh nyata terhadap presentase daya perkecambahan kopi, hal ini dapat dilihat pada tabel 1 berikut ini.

Tabel 1. Rerata Pengamatan Pengaruh Media Tanam dan Berat Benih terhadap Persentase Daya Perkecambahan Kopi Arabica

\begin{tabular}{ccccc}
\hline \multirow{2}{*}{ Perlakuan } & $\mathbf{4}$ hss & $\mathbf{1 7}$ hss & $\mathbf{2 0 ~ h s s}$ & $\mathbf{2 3 ~ h s s}$ \\
\hline M0 & $16 \mathrm{a}$ & 65 & $73 \mathrm{a}$ & $83 \mathrm{a}$ \\
M1 & $20 \mathrm{ab}$ & 65 & $75 \mathrm{ab}$ & $85 \mathrm{ab}$ \\
M2 & $21 \mathrm{~b}$ & 67 & $76 \mathrm{ab}$ & $86 \mathrm{ab}$ \\
M3 & $23 \mathrm{~b}$ & 70 & $78 \mathrm{c}$ & $88 \mathrm{~b}$ \\
\hline \multicolumn{7}{c}{ B1 } & $\mathbf{0 , 1 7}$ & tn & $\mathbf{0 , 0 9}$ & $\mathbf{0 , 0 9}$ \\
\hline B2 & $18 \mathrm{a}$ & $69 \mathrm{a}$ & $72 \mathrm{a}$ & $8,2 \mathrm{a}$ \\
B3 & $20 \mathrm{ab}$ & $70 \mathrm{~b}$ & $75 \mathrm{~b}$ & $85 \mathrm{~b}$ \\
\hline BNJ 5\% & $22 \mathrm{~b}$ & $\mathbf{0 , 9 5}$ & $\mathbf{0 , 8 1} \mathrm{c}$ & $\mathbf{0 , 8 1}$ \\
\hline Keterangan: & Angka-angka yang diikuti dengan huruf yang sama pada satu kolom menunjukkan \\
& tidak berbeda nyata berdasakan uji BNJ 5\% &
\end{tabular}

$\begin{array}{rrrr}\text { Berdasarkan } & \text { pengamatan } & \text { pada Tabel } 1 \text { menunjukan bahwa } \\ \text { rerata persentase perkecambahan } & \text { media tanam terdapat perbedaan }\end{array}$


yang sangat nyata pada pengamatan 14 hss dimana perlakuan M0 lebih rendah disbanding perlakuan lainnya. Pengaruh nyata juga bisa dilihat pada pengamatan 20 hss dan 23 hss. Pada pengamatan 17 hss persentase daya perkecambahan tidak berpengaruh nyata.

Hasil analisis ragam menunjukkan bahwa tidak terdapat pengaruh interaksi yang nyata pada perlakuan media tanam (M) dan berat benih kopi terhadap tinggi tanaman. Namun, dari hasil analisis ragam dapat diketahui bahwa terdapat pengaruh nyata antara perlakuan berat benih kopi Arabica
(B) terhadap parameter tinggi tanaman kopi $(\mathrm{cm})$ pada pengamatan 30 hari setelah tanam (hst). Perlakuan Media Tanam berpengaruh nyata terhadap parameter tinggi tanaman pada pengukuran 58 hari setelah tanam (hst). Pada pengamatan tinggi tanaman umur 58 hst, perlakuan M0 menunjukkan hasil sebesar $5,43 \mathrm{~cm}$ berbeda nyata terhadap terhadap perlakuan M1 sebesar 5,65 $\mathrm{cm}$ dan perlakuan M2 sebesar $5,76 \mathrm{~cm}$

Pengaruh faktor tunggal $\mathrm{M}$ dan $\mathrm{B}$ terhadap pertumbuhan tinggi tanaman dapat dilihat pada Tabel 2 .

Tabel. 2. Rerata Pengamatan Pengaruh Media Tanam dan Berat Benih Terhadap Pertumbuhan Tinggi Tanaman

\begin{tabular}{ccccc}
\hline \multirow{2}{*}{ Perlakuan } & \multicolumn{5}{c}{ Pengamatan Tinggi tanaman (cm) } \\
& 30 hst & $\mathbf{4 4}$ hst & $\mathbf{5 8}$ hst & $\mathbf{7 2}$ hst \\
\hline M0 & 1,31 & 3,17 & $5,43 \mathrm{a}$ & 1,14 \\
M1 & 1,4 & 3,36 & $5,65 \mathrm{ab}$ & 7,38 \\
M2 & 1,43 & 3,38 & $5,76 \mathrm{bc}$ & 7,46 \\
M3 & 1,45 & 3,45 & $6,02 \mathrm{c}$ & 7,47 \\
\hline BNJ 5\% & tn & tn & $\mathbf{0 , 1 2}$ & tn \\
\hline B1 & $1,28 \mathrm{a}$ & 3,75 & 5,65 & 7,3 \\
B2 & $1,35 \mathrm{ab}$ & 3,37 & 5,7 & 7,31 \\
B3 & $1,55 \mathrm{~b}$ & 3,39 & 5,8 & 7,49 \\
\hline BNJ 5\% & $\mathbf{0 , 1 4}$ & tn & tn & tn \\
\hline
\end{tabular}

Keterangan : Angka - angka yang diikuti dengan huruf yang sama pada satu kolom menunjukkan tidak berbeda nyata berdasakan uji BNJ 5\% $\mathrm{tn}=$ tidak berpengaruh nyata. 
Pada pengamatan tinggi tanaman menunjukkan perlakuan berat benih dan media tanam pada umur 58, 73 hst tidak menunjukkan perbedaan nyata

Hasil analisis ragam menunjukkan bahwa terdapat pengaruh interaksi yang nyata.
Adanya interaksi nyata pada perlakuan terhadap parameter jumlah daun kopi terjadi pada umur pengamatan 30, 58, dan 72 hari setelah tanam (hst).

Tabel 3. Pengaruh Media Tanam dan Berat Benih Terhadap Jumlah Daun Tanaman Kopi Arabika

\begin{tabular}{|c|c|c|c|c|}
\hline \multirow{2}{*}{ Perlakuan } & \multicolumn{4}{|c|}{ jumlah daun } \\
\hline & 30 hst & 44 hst & 58 hst & $72 \mathrm{hst}$ \\
\hline M0 & 0,88 & 2,11 & 3,22 & 4,44 \\
\hline M1 & 1,22 & 2,22 & 3,33 & 4,77 \\
\hline M2 & 1,33 & 2,33 & 3,55 & 4,77 \\
\hline M3 & 1,44 & 2,44 & 3,88 & 5 \\
\hline BNJ 5\% & tn & tn & tn & tn \\
\hline B1 & $0,91 \mathrm{a}$ & 2,08 & $3,25 \mathrm{a}$ & $4,41 \mathrm{a}$ \\
\hline B2 & $1,16 a b$ & 2,16 & $3,33 \mathrm{ab}$ & $\begin{array}{c}4,58 \\
a b\end{array}$ \\
\hline B3 & $1,58 \mathrm{~b}$ & 2,58 & $3,91 \mathrm{~b}$ & $5,25 \mathrm{c}$ \\
\hline BNJ 5\% & $\mathbf{0 , 1 1}$ & tn & 0,54 & 0,63 \\
\hline erangan: $\mathrm{A}$ & $\begin{array}{l}\text { a yang d } \\
\text { tidak be } \\
\text { pengarul }\end{array}$ & $\begin{array}{l}\text { huruf } \\
\text { erdasa }\end{array}$ & $\begin{array}{l}\text { ada satu } \\
5 \%\end{array}$ & \\
\hline
\end{tabular}

Pada analisis rata-rata jumlah daun di atas bisa dilihat bahwa pengaruh interaksi perlakuan $\mathrm{M}$ dan B tidak berbeda nyata terhadap jumlah daun kopi.

\section{Bedasarkan Uji lanjut} perlakuan berat benih terhadap pertumbuhan jumlah daun tanaman kopi arabika pada pengamatan $30 \mathrm{hst}$ menunjukkan pengaruh nyata yaitu perlakuan B3 dan B2 lebih tinggi dari pada B1. Berdasarkan analisis ini dapat diketahui bahwa berat benih kopi arabika sangat mempengaruhi pertumbuhan daun bibit tanaman kopi arabika (Coffea arabica L.).

Pada pengamatan pengaruh media tanam dan berat benih 
terhadap pertumbuhn vegetatif awal kopi arabika menunjukkan bahwa perlakuan B3 nilai pengamatan lebih besar, hal ini sesuai dngan pernyataan Sutopo 2004, bahwa benih yang berukuran besar memimliki kemampuan untuk menjadi kecambah dan memiliki vigor yang bagus, atau dengan kata lain bahwa semakin besar ukuran benih maka viabilitas, vigor dan pertumbuhan bibitnya akan semakin bagus.

\section{KESIMPULAN}

Kombinasi perlakuan media tanam dan berat benih kopi arabika tidak berpengaruh nyata terhadap persentase daya tumbuh benih dan tinggi bibit. Masing-masing perlakuan media tanam dan perlakuan berat benih berpengaruh nyata terhadap persentase perkecambahan benih kopi dan tinggi bibit kopi.

Perlakuan media tanam M3 mengakibatkan daya kecambah yang paling tinggi, begitu pula dengan perlakuan berat benih B3. Hal yang sama berlaku juga untuk variabel pengamatan tinggi bibit kopi arabika.

\section{DAFTAR PUSTAKA}

Anonimous. 2011. Luas areal dan produksi perkebunan seluruh Indonesia menurut provinsi dan status pengusahaan:komoditas kopi.http://www.ditjenbun. go.id [diakses 4 Januari 2010]

Hartono. 2013. Produksi kopi nusantara ketiga terbesar di dunia [Internet].[diunduh pada: 2013 Nov 3. Tersedia pada: http://www.kemenperin.go.id /artikel/6611Hendri, 2010.

Kartasapoetra, G. 1992. Teknologi Penyuluhan Pertanian. Bina Aksara. Jakarta.

Lingga, P. 1998. Petunjuk Penggunaan Pupuk. Penebar Swadaya, Jakarta.

Sari, R. R., A. Marliah, A. Ihsan dan Hereri. 2019. Pengaruh Komposisi Media Tanam dan Dosis NPK terhadap Pertumbuhan Bibit Kopi Robusta (Coffea chanephora L.). Jurnal Agrium. Fakultas Pertanian, Universitas Malikussaleh. 16 (1): 28-37. DOI: https://doi.org/10.29103/ agrium.v16i1.1339.

Sutopo, L. 2004. Teknologi Biji. Gravindo Persada. Jakarta. 